\title{
Nutrition and environmental sustainability
}

\author{
J.Y. Dourmad ${ }^{1}{ }^{*}$, F. Garcia-Launay ${ }^{1}$, B. Méda ${ }^{2}$, M. Lessire ${ }^{2}$ and A. Narcy ${ }^{2}$ \\ ${ }^{1}$ PEGASE, INRA Agrocampus Ouest, 35590 Saint- \\ Gilles, France; ${ }^{2}$ BOA, INRA, Université de Tours, 37380 \\ Nouzilly, France; jean-yves.dourmad@inra.fr
}

\section{Summary points}

- Diet formulation has a direct impact on the efficiency of use of nutrient and energy by pigs and poultry and, consequently, it affects nutrient and waste flow at farm level.

- All the compounds found in the manure, or emitted into the air, originate from the fraction of the diet which is not retained by the animals.

- The improvement of efficiency of nutrient retention by pigs and poultry is an efficient way to reduce excretion and emission from the animals.

- Changing the composition of the feed is efficient to modify the chemical properties of excreta in order to reduce the gaseous emissions and the production of odours.

- Changing the composition if the feed may allow to better adapt the composition of excreta to their future use for biogas production or as fertilisers.

- Innovations in the development of enzymes and amino acid production have been and are still important levers for the development of low environmental impact feeding strategies for pigs and poultry.

- The development of feeding strategies for reducing $\mathrm{N}$ and $\mathrm{P}$ excretion by pigs and poultry requires a good knowledge of nutrient bioavailability in feed ingredients and a precise evaluation of requirements.

- Phase feeding is required for practical application of improved feeding strategies. It is facilitated by the use of computerised feeding systems with the perspective of precision feeding.

Keywords: pig, poultry, nutrition, environment 


\subsection{Introduction}

For a sustainable pig and poultry production, emission of pollutants and use of non-renewable resources should be decreased over the whole production process, as much as possible. Nitrates and phosphates originating from pig and poultry manure contribute to eutrophication of freshwater or seawater. In addition, the world reserves of mineral phosphates are limited and should be preserved. The accumulation of $\mathrm{Cu}$ and $\mathrm{Zn}$ in soils may impose a medium or long term toxicity risk on plants and soil micro-organisms, and increases the risk of their transfer to water ecosystems. Ammonia $\left(\mathrm{NH}_{3}\right)$ emission from manure is involved in acidification and eutrophication, with recognised detrimental effects on forests, soils, and biodiversity. Ammonia also contributes to the emission of small particles to the air, with possible detrimental effects on human and animal health. Although lower than in ruminants, the raising of monogastric animals also contributes to direct emissions of greenhouse gas, especially methane $\left(\mathrm{CH}_{4}\right)$ from enteric fermentation in pigs, and $\mathrm{CH}_{4}$ and nitrous oxide $\left(\mathrm{N}_{2} \mathrm{O}\right)$ emissions from slurry and litter.

Diet formulation has a direct impact on the efficiency of use of nutrient and energy by the animals and, consequently, it affects nutrient and waste flow at a farm level (Petersen et al., 2007). All the nutrients found in the manure, or emitted into the air, originate from the fraction of the feed which is not retained by the animal, indicating that the manipulation of the diet can be an efficient way to control the amount and chemical composition of manure produced, and the emissions of pollutants to the environment.

Over the last decades, different ways to reduce the environmental impact of pig and poultry production have been investigated. The nutritional approach has received great attention from researchers and legislative decision makers (Jongbloed et al., 1999b; Aarnink and Verstegen, 2007). It mainly relies on improvements in our knowledge of the physiology of pigs and poultry in order to achieve a better agreement between supply and requirement and improve nutrient bioavailability in feedstuffs. The main strategies that have been investigated are: (1) the improvement of efficiency of nutrient use in order to reduce excretion and emissions from the animals; (2) the modification of chemical properties of excreta in order to reduce the gaseous emissions and the production of odours from manure; (3) the better adaptation of excreta to their future use for energy production or as fertilisers in different strategies of valorisation with or without treatment.

The aim of this chapter is to provide an overview of the scientific knowledge regarding the nutritional possibilities to reduce $\mathrm{N}, \mathrm{P}, \mathrm{Cu}$ and $\mathrm{Zn}$ excretion by pigs and poultry, as well as emission of $\mathrm{NH}_{3}$ and greenhouse gas and odours, and to describe the means that could be or are already implemented in practice. The environmental impacts related to the production of feeds and feed ingredients are not considered in this chapter but are discussed elsewhere. 


\subsection{Improvement of efficiency of use of protein}

\subsubsection{Efficiency of protein in pigs}

The efficiency of protein utilisation by pigs depends on the dietary composition and the physiological status or the growth stage of the animals. In growing-finishing pigs fed a cereal-soybean meal diet, approximately $32 \%$ of the $\mathrm{N}$ intake is retained (Dourmad et al., 1999b). Faecal $\mathrm{N}$ excretion which consists of the undigested protein fraction of the feed and endogenous losses amounts to approximately $17 \%$ of the intake depending of the protein sources used. Digested proteins are absorbed as amino acids which can subsequently be used for protein synthesis. Obligatory losses of amino acids relate to digestion, protein metabolism (synthesis, degradation and turnover), and renewal of skin and hair. The remaining digestible amino acids, after protein deposition and obligatory losses, are catabolised and excreted mainly as urea. With conventional diets this latter fraction is often the most important. Average efficiency of $\mathrm{N}$ retention is lowest in sows (20-30\%), intermediate in growing pigs (30-40\%), and highest in weaners (45-55\%) (Dourmad et al., 1999a).

Two complementary nutritional approaches can be used to improve the efficiency of protein utilisation in pigs and, consequently, to reduce $\mathrm{N}$ excretion. The first approach is to ensure adequate protein/amino acid supply over time according to the growth potential of the animals or their physiological state. This requires a joint fitting of daily supply of energy and protein (amino acids), depending on genetic potential and stage of production. In sows, $\mathrm{N}$ excretion is reduced by 20 to $25 \%$ when different diets are allocated for pregnancy and for lactation instead of a single diet. This is now implemented on most farms. Further improvements could be achieved with the use of two- or multi-phase feeding during pregnancy. This requires a precise evaluation of requirements, which can be achieved using modelling tools. Dourmad et al. (2014) calculated that two- and multi-phase feeding strategies during pregnancy resulted in 10 and $14 \%$ reduction of protein intake, 15 and $20 \%$ reduction of $\mathrm{N}$ excretion over the whole reproductive cycle, and 6 and $8 \%$ reduction of feeding cost, respectively. Although such feeding strategies can be implemented in practice with the use of automated feeding stations that allow the mixing of two feeds differing in their nutrient contents, they are not yet commonly used in practice. In the same way the distribution of tailored diets resulting from the mixing of two feeds could also be considered for lactating sows in the future. In fattening pigs, phase feeding is also an efficient way to improve protein efficiency. Latimier and Dourmad (1993) reported an approximate $10 \%$ reduction in slurry $\mathrm{N}$ when different diets were applied during the growing and finishing periods, compared to feeding the same diet during both periods. A further 5 to $12 \%$ reduction in $\mathrm{N}$ excretion can be achieved by increasing the number of diets used over the fattening period or with weekly or daily multi-phase group feeding (Bourdon et al., 1997; Pomar et al., 2014). With the use of individual 
precision feeding in the future (Chapter 18, Pomar et al., 2019) each pig will receive the exact amount of nutrients according to its own expected performance and housing conditions allowing to tackle the between pig variability in protein requirements. Compared to a three-phase feeding strategy, precision feeding allowed the reduction of protein intake by $14 \%$ and $\mathrm{N}$ excretion by $22 \%$ (Andretta et al., 2014).

The second nutritional approach to increase the efficiency of protein retention in pigs is to improve the dietary digestible amino acid balance, which allows reducing crude protein (CP) content of the diet. This can be obtained through a combination of different protein sources and/or the substitution of protein by inclusion of feed-use amino acids in a free form. In fattening pigs, Dourmad et al. (1993) measured a 35\% reduction of $\mathrm{N}$ excretion after improvements in the dietary amino acid profile without affecting feed intake, average daily gain, feed efficiency and carcass composition. In the past there has been some controversy regarding the effect of reducing $\mathrm{CP}$ content on animal performance and especially on carcass composition with some studies indicating an increase in fat deposition with low protein diets. This was often related to the formulation of diets on a metabolisable or digestible energy basis, resulting in a higher net energy content for low protein diets, and consequently lower amino acid to net energy ratio. Moreover, diets were often formulated on crude and not digestible amino acid contents, increasing the risk of deficiency in second amino acids and higher fat deposition. The development of net energy and ileal digestible amino acid systems is thus an important step to secure the formulation of low protein diets for pigs.

The ultimate reduction of $\mathrm{N}$ excretion can be reached when multi-phase feeding is combined with a perfect balance between essential amino acids (close to the ideal protein), and with an optimisation of the supply of non-essential amino acids. Such a feeding strategy has been evaluated experimentally in fattening pigs by Bourdon et al. (1997). In that study, the use of a single diet (17.5\% CP) over the whole growingfinishing period was compared to a 'multi-phase' strategy which consisted of the mixing of two diets ( 13.0 and $10.7 \% \mathrm{CP}$, re-equilibrated with free amino acids) in proportions that were optimised each week. Growth performance and carcass quality were similar, and $\mathrm{N}$ excretion was reduced by approximately $50 \%$. With this feeding strategy, $\mathrm{N}$ excretion represented only $50 \%$ of $\mathrm{N}$ intake. This can be considered to be close to the technically maximal attainable reduction in $\mathrm{N}$ excretion for fattening pigs.

It must be pointed out that the development of such feeding techniques for reducing $\mathrm{N}$ excretion by pigs requires good knowledge of the amino acid availability in feedstuffs, and of the changes in amino acid requirements according to growing stage or physiological state. This is now within reach with the use of modelling techniques for predicting requirements (Dourmad et al., 2008; Van Milgen et al., 2008; NRC, 2012) together with a better knowledge of variations in amino acid availability in feedstuffs (CVB, 2000; Sauvant et al., 2004; NRC, 2012). Moreover, more numerous amino acids 
are now available for feed use (lysine, methionine, threonine, tryptophan and valine) which allows a further reduction in dietary protein content. This can also be achieved in practice by using computerised blend feeding systems which allow adapting the diet composition on a daily or weekly basis (Feddes et al., 2000; Pomar et al., 2007).

The reduction in dietary protein content results in a lower proportion of $\mathrm{N}$ excreted in urine relative to faeces, which might affect the utilisation of manure $\mathrm{N}$ after field application (Sørensen and Fernandez, 2003). In the study of Portejoie et al. (2003), the ratio $\mathrm{NH}_{3}-\mathrm{N}$ :total $\mathrm{N}$ in fresh manure decreased from 0.79 with the $20 \%$ to 0.63 with the 12\% CP diet. However, according to Gerdemann et al. (2000) and Sørensen and Fernandez (2003), the availability of slurry $\mathrm{N}$ for the plant was not affected by the dietary protein content.

Feeding strategies with reduced protein content are already implemented in practice in many countries. Different strategies are compared in Table 15.1. The first twostrategies correspond to the hypothesis used for the official calculation of $\mathrm{N}$ excretion in France (Corpen, 2003). Compared to the one-phase feeding strategy without any constraints on protein content, used as reference, the two-phase feeding strategy with limited $\mathrm{CP}$ contents, reduces $\mathrm{N}$ intake and $\mathrm{N}$ excretion by 10 and $15 \%$, respectively. A further reduction in dietary $\mathrm{CP}$ and consequently $\mathrm{N}$ excretion, could be achieved in a relatively short term by incorporation of more amino acids in free form, which means in practice to relax the minimum constraint on $\mathrm{CP}$, and using multiphase feeding for fattening pigs (Garcia-Launay et al., 2014, Table 15.1). However the development of such techniques is dependent on technical and economic considerations.

\subsubsection{Efficiency of protein retention in poultry}

In the same way as for pigs, protein retention in poultry depends on the dietary protein level and the physiological stage of the bird. Amino acids from digested feedstuffs are absorbed and used for protein metabolism. Excess of digestible amino acids and obligatory losses related to metabolism are catabolised and excreted as uric acid. Undigested proteins as well as the endogenous urinary and faecal protein losses are also excreted. As a consequence, $\mathrm{N}$ excretion and retention depend on the quality of consumed raw materials (protein digestibility), the amino acid balance of the diet and the difference between birds' amino acid requirements and their supply. Thus, improving efficiency of protein retention requires a perfect knowledge of animals' requirements and raw material compositions. When this is not the case, as often is in practice, safety margins are taken which increase losses and reduces the efficacy of production.

To reduce $\mathrm{N}$ excretion and improve $\mathrm{N}$ retention efficiency, $\mathrm{CP}$ content of the diet is adjusted to physiological stage of the bird. For instance modern broilers are generally fed four different diets, or more, throughout their life, according to phase feeding 
Table 15.1. Effect of protein feeding strategy of sows and fattening pigs on crude protein (CP) and nitrogen $(\mathrm{N})$ excretion per slaughter pig produced (Corpen, 2003; Garcia-Launay et al., 2014).

\begin{tabular}{|c|c|c|c|c|}
\hline & \multicolumn{2}{|c|}{ Actual (Corpen, 2003) } & \multicolumn{2}{|c|}{ Perspectives (Garcia-Launay et al., 2013) } \\
\hline & 'One-phase' & Two-phase & Two-phase & Multi-phase \\
\hline \multicolumn{5}{|l|}{$\mathrm{CP}(\mathrm{g} / \mathrm{kg})$} \\
\hline Gestation & 170 & 140 & 120 & 120 \\
\hline Lactation & 170 & 165 & 155 & 155 \\
\hline Pre-starter & 210 & 200 & 180 & 180 \\
\hline Starter & 190 & 180 & 160 & 160 \\
\hline Grower & 175 & 165 & 150 & 150 \\
\hline Finisher & 175 & 150 & 130 & 110 \\
\hline Average & 177 & 158 & 140 & 131 \\
\hline \multicolumn{5}{|c|}{$\mathrm{N}$ per pig $(0-115 \mathrm{~kg} B W)(\mathrm{kg})$} \\
\hline Intake & 9.10 & 8.16 & 7.23 & 6.78 \\
\hline Retention & 2.89 & 2.89 & 2.89 & 2.89 \\
\hline Excretion & 6.06 & 5.13 & 4.22 & 3.78 \\
\hline$\%$ of standard & 100 & 85 & 70 & 63 \\
\hline
\end{tabular}

strategies. Reducing protein content of the diets can be achieved by adding feed-use amino acids such as L-lysine, DL-methionine, L-tryptophan, or amino acid analogue such as hydroxyl methylthio butanoic acid, in order to reach an optimum profile of digestible amino acids (Mack et al., 1999). Meda et al. (2011) calculated that each $10 \mathrm{~g} / \mathrm{kg}$ reduction in dietary CP in layers and broilers resulted in $10 \%$ reduction of $\mathrm{N}$ excretion. A similar reduction was observed in ducks by Baeza et al. (2012) and Van Cauvenberghe and Burnham (2001) in broilers. However, poultry seem to be more sensitive than pigs to a reduction in dietary protein. For instance, Leclercq (1996) observed that a reduction of $10 \mathrm{~g} \mathrm{CP} / \mathrm{kg}$ feed significantly reduced $\mathrm{N}$ excretion, but increased feed conversion ratio by $0.021 \mathrm{~kg} / \mathrm{kg}$. Aftab et al. (2008) concluded that above $10 \%$ reduction of $\mathrm{CP}$ (compared to NRC recommendations), broilers performance might be reduced. Inadequate essential/non-essential amino acids or net energy/ metabolisable energy ratios were suggested by these authors as possible reasons to explain these effects. This is confirmed with the recent study of Belloir et al. (2017) in which dietary protein content was reduced by $20-30 \mathrm{~g} \mathrm{CP} / \mathrm{kg}$ feed in finishing broilers without any negative consequences on growth performance. Nitrogen excretion was reduced by $13 \%$ for each $10 \mathrm{~g}$ decrease of $\mathrm{CP} / \mathrm{kg}$ feed, resulting in an increase of 3.4 percentage points of retention efficiency. In turkey, Travel et al. (2005) found that an 
important reduction in dietary $\mathrm{CP}$ during the finishing period reduced $\mathrm{N}$ excretion by $37 \%$, did not affect growth performance but tended to reduce breast meat yield.

Efficiency of protein retention in poultry is also affected by the type of production (Corpen, 2003). The lowest efficiency is observed for laying hens (28\%) and the highest (54\%) for conventional broilers. Efficiency is reduced in slow growing/high meat quality and free range broilers (36 and 33\%, respectively). The efficiency of turkey is intermediate (46\%). The lowest efficiency for protein retention is generally found in organic poultry production systems, mainly because industrially manufactured amino acids are not allowed to be used.

\subsection{Improvement of efficiency of use of minerals}

\subsubsection{Phosphorus}

To reduce $\mathrm{P}$ excretion, $\mathrm{P}$ supplied to pigs and poultry should be adjusted to their requirement, and strategies to improve $\mathrm{P}$ bio-availability should be implemented (Poulsen, 2000; Knowlton et al., 2004). This relies on an accurate knowledge of $\mathrm{P}$ requirement according to the physiological status of pigs and poultry, and of feed $\mathrm{P}$ bio-availability, including the effect of the addition of enzymes. Indeed with diets based only on cereal, soybean meal and minerals, the efficiency of P retention is rather low. For instance, with such diets in growing-finishing pigs, approximately $45 \%$ of the $\mathrm{P}$ intake is absorbed, $30 \%$ is retained, and the remaining $15 \%$ is excreted via urine (Poulsen et al., 1999). In growing chickens, the absorption of $\mathrm{P}$ intake is approximately 57\% and retention 50\% (Plumstead et al., 2008).

The most efficient approach to increase P retention efficiency and reduce excretion is to improve digestibility of $\mathrm{P}$. This can be achieved with use of highly digestible mineral $\mathrm{P}$ supplements. For example, monocalcium rather than dicalcium phosphate can be used because of its much higher digestibility in pigs and poultry (Sauvant et al., 2004). However, most strategies implemented to reduce $\mathrm{P}$ excretion by pigs and poultry refer to improvements in phytic $P$ utilisation (Jongbloed et al., 1992). Indeed, monogastric animals do not produce phytase, and this enzyme is required for the hydrolysis in the stomach of phytic acid which is the main form of $\mathrm{P}$ in cereals and meals. Some feed ingredients (wheat and wheat by products, rye, triticale, etc.) contain significant amounts of natural phytase, but this phytase is sensitive to high temperature and may be inactivated in the pelleting process. This is why two $\mathrm{P}$ digestibility value are proposed (Sauvant et al., 2004) depending if the feed is pelleted or not. However, microbial phytase which is currently used in many countries, appears the most efficient to increase P digestibility. Total P supply may be decreased, resulting in reduced $\mathrm{P}$ excretion up to 40 to 50\% (Jongbloed and Lenis, 1992; Latimier et al., 1994; 
Frapin, 1996, Juin et al., 2001; Lelis et al., 2010). This strategy proved to be efficient in most poultry species: growing and finishing broilers (Létourneau et al., 2010a; Rousseau et al., 2012; Bougouin et al., 2014), laying hens (Ahmadi and Rodehutscord, 2012), turkeys (Maguire et al., 2005) and ducks (Adeola, 2010). Different types of phytase are available on the market, their efficiency and sensitivity to temperature may differ (Igbasan et al., 2000). However, for all of them, the response of digestible $\mathrm{P}$ to graded levels of microbial phytase is curvilinear, and the maximum $P$ digestibility never exceeds 60-70\%, even at high levels of phytase supplementation. Based on literature reviews, equivalency equations of digestible $\mathrm{P}$ for microbial phytase have been established (Kornegay, 2001; Johansen and Poulsen, 2003) and can be used for diet formulation. The adjustment of the Ca:P ratio in combination with phytase is recognised as a valuable strategy to improve $P$ retention in pigs and poultry (Plumstead et al., 2008; Létourneau et al., 2010b).

In the same way as for protein and amino acid supply, the second approach to reduce $\mathrm{P}$ excretion is to ensure adequate supply over time according to the growth potential of the animals or their physiological status. This requires a precise evaluation of $\mathrm{P}$ requirements, as well as $\mathrm{P}$ availability in feed ingredients. In pigs, this can be achieved in practice by the use of a feeding system relying on, $\mathrm{P}$ apparent digestibility (CVB, 2000; Sauvant et al., 2004) or bioavailability (NRC, 2012), and the factorial determination of P requirements (Jongbloed et al., 1999a; Jondreville and Dourmad, 2005; NRC 2012). In poultry, different systems of available $\mathrm{P}$ coexist based on phytate and non-phytate P feed content (NRC, 1994; GfE, 1999), P relative bioavailability (Sauvant et al., 2004) or retention (CVB, 2000). Although a factorial approach was previously proposed to determine $\mathrm{P}$ requirements (Sauveur, 1985), more global methods based on the maximisation of growth performance or bone mineralisation are generally employed. Currently, a common European P system is under consideration. Finally, this allows the lowering of safety margins when formulating diets, resulting in a decrease in $\mathrm{P}$ excretion.

Feeding strategies with reduced $\mathrm{P}$ content are already implemented in practice in many countries. Different strategies are compared in pigs (Table 15.2) and broilers (Table 15.3). In pigs, the first two-strategies correspond to the hypothesis used for the official calculation of P excretion in France (Corpen, 2003). Compared to the onephase feeding strategy used as a reference, the two-phase feeding strategy with limited $\mathrm{P}$ content reduces $\mathrm{P}$ intake and $\mathrm{P}$ excretion by 13 and 19\%, respectively. A further reduction in dietary $\mathrm{P}$ and consequently $\mathrm{P}$ excretion could be achieved in a relatively short term by using higher levels of phytase and by using multi-phase feeding for fattening pigs (Table 15.2, perspective). In broilers, the use of 750 phytase units (FTU) microbial phytase results in $36 \%$ reduction of $\mathrm{P}$ excretion (Table 15.3). 
Table 15.2. Phosphorus $(\mathrm{P})$ feeding strategy and $\mathrm{P}$ excretion of pigs.

\begin{tabular}{llll} 
& \multicolumn{2}{c}{ Corpen (2003) } & \multirow{2}{*}{ Perspectives } \\
\cline { 2 - 3 } & 'One-Phase' & Two-phase & \\
\cline { 2 - 3 } P, g/kg diet & & & \\
Gestation & 6.5 & 5.0 & 4.5 \\
Lactation & 6.5 & 6.0 & 6.0 \\
Pre-starter & 7.5 & 6.8 & 6.0 \\
Starter & 6.5 & 5.8 & 5.0 \\
Grower & 5.8 & 4.8 & 4.2 \\
Finisher & 5.8 & 4.4 & 3.8 \\
Average & 6.0 & 4.9 & 4.3 \\
P per (0-115 kg), kg & & & \\
Intake & 1.91 & 1.54 & 1.35 \\
Retention & 0.60 & 0.60 & 0.60 \\
Excretion & 1.31 & 0.94 & 0.76 \\
\% of standard & 100 & 72 & 58
\end{tabular}

Table 15.3. Influence of dietary microbial phytase addition on phosphorus $(\mathrm{P})$ excretion of broiler chickens.

\begin{tabular}{lll} 
Item & Standard & Standard +750 phytase units $/ \mathrm{kg}$ microbial phytase \\
\hline P, g/kg & & \\
Starter & 7.5 & 6.5 \\
Grower & 6.5 & 5.5 \\
Finisher & 6.0 & 5.0 \\
P per chicken $(\mathrm{g})^{1}$ & & \\
Intake & 19 & 16 \\
Retention & 11 & 11 \\
Excretion & 8.5 & 5.4 \\
\% of standard & 100 & 64 \\
\hline${ }^{1}$ Final body weight: $1.9 \mathrm{~kg}$. & &
\end{tabular}




\subsubsection{Copper and zinc}

Copper $(\mathrm{Cu})$ and zinc $(\mathrm{Zn})$ are involved in many metabolic functions, and their provision in sufficient amounts in feed is indispensable to ensure good performance and animal health (Jondreville et al., 2002; Revy et al., 2003). However, because they are used as growth promoters at pharmacological levels (Poulsen, 1995), or because large safety margins are applied, $\mathrm{Cu}$ and $\mathrm{Zn}$ are often oversupplied in diets. Consequently, these elements are highly concentrated in manure and accumulate in soil, where they may impose a medium or long-term toxicity risk to plants and micro-organisms (Jondreville et al., 2003). Moreover, when a treatment is applied to the slurry, $\mathrm{Cu}$ and $\mathrm{Zn}$ will follow the solid fraction where their concentration often exceeds the maximal values allowed for the utilisation of these products as organic fertilisers. The only way to decrease the concentration of trace element in manure is to restrict their incorporation in the diet.

The incorporation of 150 to $250 \mathrm{mg} / \mathrm{kg} \mathrm{Cu}$ in pig diets has been employed for a long time because of its growth promoting effect (Braude, 1980). Accordingly, $\mathrm{Cu}$ is routinely fed commercially to broiler chickens at high pharmacological levels. This practice is currently authorised in the EU allowing diets containing a maximum of $170 \mathrm{mg} / \mathrm{kg} \mathrm{Cu}$ for pigs up to 12 weeks. After 12 weeks of age, the use of $\mathrm{Cu}$ as a growth factor is no longer allowed within the EU, and the maximal level of incorporation is $25 \mathrm{mg} / \mathrm{kg}$ as for all poultry species. Compared to the former allowed inclusion ( $175 \mathrm{mg} / \mathrm{kg}$ up to 16 weeks of age and $100 \mathrm{mg} / \mathrm{kg}$ thereafter (Table 15.4, 'former'), this results in a drastic reduction of $\mathrm{Cu}$ in manure by almost $60 \%$ (Table 15.4, 'actual'). Nevertheless, the practical supply for pigs and poultry remains higher than the usually published requirements (less than $10 \mathrm{mg} / \mathrm{kg}$ ), and average retention efficiency is still less than $1 \%$ for pigs and $6 \%$ for chickens.

Supplementing weaned piglet diets with 1,500 to $3,000 \mathrm{mg} / \mathrm{kg} \mathrm{Zn}$ as $\mathrm{ZnO}$ has also been reported to prevent or overcome post-weaning diarrhoea and stimulate their growth (ANSES, 2013; Sales, 2013). In 2003, the maximal allowed Zn incorporation in pig diets was reduced to $150 \mathrm{mg} / \mathrm{kg}$, compared to $250 \mathrm{mg} / \mathrm{kg}$ before. More recently, EFSA (2014) pointed out the high potential for $\mathrm{Zn}$ reduction in animal feed and recommended a reduction from 150 to $100 \mathrm{mg} / \mathrm{kg}$ of $\mathrm{Zn}$ for pigs for fattening and most poultry species except for turkeys for fattening $(120 \mathrm{mg} / \mathrm{kg})$. Consecutively, a $31 \%$ reduction in $\mathrm{Zn}$ emission could be achieved for pigs for fattening that could reach $53 \%$ when phytase is used (EFSA, 2014). These levels are much closer to the published requirement, which varies between 45 and $150 \mathrm{mg} / \mathrm{kg}$ for pigs and from 35 to $120 \mathrm{mg} / \mathrm{kg}$ for poultry species depending on growing stage and authors (NRC, 1994; Gfe, 1999; IFZZ, 2005; Revy et al., 2005; MTT, 2013). However, in some EU countries supplementation with $2,500 \mathrm{mg} / \mathrm{kg} \mathrm{Zn}$ is still allowed as medication, resulting in an drastically increased excretion. 
Table 15.4. Estimates of copper and zinc balance ${ }^{1}$ according to different scenarios of supply (former EU regulation, actual EU regulation and perspectives) in pig feeding.

\begin{tabular}{|c|c|c|c|c|c|c|c|}
\hline \multirow[t]{2}{*}{ Item } & \multicolumn{3}{|l|}{ Copper } & \multicolumn{4}{|l|}{ Zinc } \\
\hline & Former & Actual & Persp. & Former & Actual & 'Actual'3 & Persp. \\
\hline \multicolumn{8}{|l|}{ Concentration $(\mathrm{mg} / \mathrm{kg})$} \\
\hline Prestarter & 175 & 170 & 10 & 250 & 150 & 2,000 & 70 \\
\hline Starter & 175 & 170 & 10 & 250 & 150 & 150 & 50 \\
\hline Fattening pigs & 120 & 25 & 10 & 250 & 120 & 120 & 30 \\
\hline Sows & 100 & 25 & 10 & 250 & 150 & 150 & 70 \\
\hline \multicolumn{8}{|l|}{ Balance (0-110 kg BW) } \\
\hline Intake (g/pig) & 40.4 & 13.0 & 3.1 & 78.3 & 40.1 & 53.0 & 12.2 \\
\hline Excreted (g/pig) & 40.3 & 12.9 & 3.0 & 75.8 & 37.6 & 50.6 & 9.7 \\
\hline Slurry (mg/kg DM) & 1,060 & 348 & 80 & 1,995 & 1000 & 1,390 & 255 \\
\hline Delay, years ${ }^{2}$ & 50 & 167 & 1,040 & 99 & 175 & 125 & 1,160 \\
\hline
\end{tabular}

As for $\mathrm{P}$, the main approach to reduce $\mathrm{Cu}$ and $\mathrm{Zn}$ in pig manure is to adjust the supply to the requirement, and to improve the availability to the animal. Zinc requirement of weaned piglets was evaluated to be approximately $90 \mathrm{mg} / \mathrm{kg} \operatorname{diet}$ (Revy et al., 2005) which is consistent with the former recommendations and below the usual level in practice. In broilers, the $\mathrm{Zn}$ requirement for maximal growth is approximately 30$40 \mathrm{mg} / \mathrm{kg}$ and ranged from 50 to $90 \mathrm{mg} / \mathrm{kg}$ for maximal plasma and bone $\mathrm{Zn}$ content (Schlegel et al., 2013). In most cases, values used by the feed industry remain higher than dietary requirements. When microbial phytase is incorporated in the diet, the $\mathrm{Zn}$ supply may be reduced because of increased bio-availability. In weaned piglets, incorporation of 500 phytase units $/ \mathrm{kg}$ diet was evaluated to be equivalent to the supply of $30 \mathrm{mg} / \mathrm{kg}$ of $\mathrm{Zn}$ as Zn sulphate (Jondreville et al., 2005). In broilers, $500 \mathrm{FTU}$ was equivalent to $5 \mathrm{mg}$ of $\mathrm{Zn}$ as sulphate (Jondreville et al., 2007). Consequently, in a maize-soybean meal based diet formulated to contain $60 \mathrm{mg} / \mathrm{kg}$ of $\mathrm{Zn}, \mathrm{Zn}$ excreted would be reduced by $10 \%$ when adding $500 \mathrm{FTU}$ of microbial phytase per kg. In broilers, compared to the present situation ( $100 \mathrm{mg} / \mathrm{kg} \mathrm{Zn} / \mathrm{kg}$ feed), $\mathrm{Zn}$ excretion by broilers would be reduced by $36 \%$ in case of a reduction to $100 \mathrm{mg} / \mathrm{kg}$ of feed, and by $77 \%$ in case of feeding according to the animal's $\mathrm{Zn}$ requirement (Table 15.5).

With the present $\mathrm{EU}$ regulation, $\mathrm{Cu}$ and $\mathrm{Zn}$ contents in pig manure dry matter (DM) ( $~ 350$ and $1,250 \mathrm{mg} / \mathrm{kg} \mathrm{DM}$, respectively) are below the maximal concentration 
Table 15.5. Estimates of zinc balance according to different scenarios of supply (current EU regulation, EU regulation perspectives and dietary requirements) in chicken feeding.

\begin{tabular}{lccc} 
Item & Current & Perspectives & Dietary requirements \\
\hline Concentration $(\mathrm{mg} / \mathrm{kg})$ & & & \\
$\quad$ Starter & 120 & 100 & 60 \\
Grower & 120 & 100 & 50 \\
Finisher & 120 & 100 & 40 \\
Balance $^{1}(\mathrm{mg} / \mathrm{bird})$ & & 309 & 134 \\
Intake $^{\text {Retention }}$ & 370 & 38 & 38 \\
Excretion & 38 & 270 & 96 \\
Relative excretion (\%) & 100 & 80 & 29 \\
\hline${ }^{1}$ Final body weight: $1.9 \mathrm{~kg}$. & & &
\end{tabular}

generally allowed in sewage sludge (1000 and 3,000 $\mathrm{mg} / \mathrm{kg} \mathrm{DM}$, respectively), but they exceed the concentration allowed for organic fertilisers (300 and $600 \mathrm{mg} / \mathrm{kg}$ $\mathrm{DM}$, respectively). Assuming that $170 \mathrm{~kg} \mathrm{~N} / \mathrm{ha}$ are spread out each year, it will take 160-170 years for the soil to reach $50 \mathrm{mg} \mathrm{Cu}$ or $150 \mathrm{mg} \mathrm{Zn} / \mathrm{kg}$ soil DM (Table 15.4). This is much longer than with the previous regulation (50 to 100 years). But although the situation has been drastically improved by this regulation, $\mathrm{Cu}$ and $\mathrm{Zn}$ inputs to soil with a manure application rate of $170 \mathrm{~kg} \mathrm{~N} / \mathrm{ha}$ still exceed the export by crops. In the future, further reductions in $\mathrm{Cu}$ and $\mathrm{Zn}$ excretion should be possible (Table 15.4, perspective), resulting in a better agreement between spreading and export by plants. However, this will require a better understanding of the factors that affect $\mathrm{Cu}$ and $\mathrm{Zn}$ availability and a more precise evaluation of the requirements.

\subsection{Effect of feeding on ammonia emissions from manure}

According to the EMEP/EEA (2013) air pollutant emission inventory guidebook, $\mathrm{NH}_{3}$ emission during storage of animal manure can be calculated as a proportion of $\mathrm{N}$ excreted or its $\mathrm{NH}_{3}$ content. According to this approach, reduction of $\mathrm{N}$ excretion, and especially of the urinary fraction, will thus result in reduction of $\mathrm{NH}_{3}$ emission. By changing feeding practices, it is possible to influence urea or uric acid concentration of excreta and the $\mathrm{pH}$ of slurry, which both affect $\mathrm{NH}_{3}$ release (Van de Peet-Schwering et al., 1999). When pigs are fed low $\mathrm{CP}$ diets, urinary urea concentration and $\mathrm{pH}$ decrease (Canh et al., 1998; Portejoie et al., 2004). When water is available ad libitum, 
feeding low CP diets also results in lower urine production due to decreased water consumption (Pfeiffer et al., 1995; Portejoie et al., 2004). These changes in slurry characteristics result in lower $\mathrm{NH}_{3}$ losses during housing, storage and following application of slurry (Canh et al., 1998; Hayes et al., 2004; Portejoie et al., 2004; Jarret et al., 2011). For instance, in the study of Portejoie et al. (2004) $\mathrm{NH}_{3}$ emissions over the whole period from excretion to field application, was decreased by $63 \%$ when dietary CP was decreased from 20 to $12 \%$ in finishing pigs (Table 15.6).

The electrolytic balance, calculated as $\left(\mathrm{Na}^{+}+\mathrm{K}^{+}-\mathrm{Cl}^{-}\right)$, is often used in pig and poultry feeding to evaluate the acidogenicity of the diet, a decrease in the electrolytic balance resulting in a decrease in urinary $\mathrm{pH}$. When dietary $\mathrm{CP}$ content is reduced, electrolytic balance decreases generally because of the high potassium $(\mathrm{K})$ content of most protein sources (INRA-AFZ, 2004). This partly explains the effect of CP on urinary $\mathrm{pH}$. However, as shown by Canh et al. (1998), more drastic changes in urinary $\mathrm{pH}$ and $\mathrm{NH}_{3}$ volatilisation can be obtained by inclusion of the calcium (Ca) salts $\mathrm{CaSO}_{4}$ or $\mathrm{CaCl}_{2}$ instead of $\mathrm{CaCO}_{3}$. The addition of Ca-benzoate (Canh et al., 1998) or benzoic acid (Guiziou et al., 2006) was also effective in reducing slurry $\mathrm{pH}$ and $\mathrm{NH}_{3}$ volatilisation (by 25 to $40 \%$ ), because these products are metabolised into hippuric acid which is rapidly excreted in urine. A similar effect (25\% reduction in $\mathrm{NH}_{3}$ emission) was observed with adipic acid (Van Kempen, 2001) which is partially excreted in urine. Some feed ingredients with a high content of sulphur have also a

Table 15.6. Effect of protein feeding of fattening pigs on slurry characteristics and ammonia volatilisation (Portejoie et al., 2004).

\begin{tabular}{|c|c|c|c|}
\hline \multirow[t]{2}{*}{ Item } & \multicolumn{3}{|c|}{ Dietary crude protein content (\%) } \\
\hline & 20 & 16 & 12 \\
\hline \multicolumn{4}{|l|}{ Slurry composition } \\
\hline Amount $(\mathrm{kg} / \mathrm{pig} / \mathrm{d})$ & 5.7 & 5.1 & 3.6 \\
\hline Dry matter $(\%)$ & 4.4 & 4.6 & 5.9 \\
\hline Total nitrogen ( $\mathrm{g} \mathrm{N} / \mathrm{kg})$ & 5.48 & 4.30 & 3.05 \\
\hline Total ammonia nitrogen ( $\mathrm{g} \mathrm{N} / \mathrm{kg}$ ) & 4.32 & 3.13 & 1.92 \\
\hline $\mathrm{pH}$ & 8.92 & 8.61 & 7.57 \\
\hline \multicolumn{4}{|l|}{ Nitrogen balance (g/pig/d) } \\
\hline Retention & 23.2 & 23.5 & 21.9 \\
\hline Excretion & 40.7 & 27.6 & 15.0 \\
\hline Ammonia-N volatilisation $^{1}$ & 17.4 & 13.8 & 6.4 \\
\hline Available to plants & 23.3 & 13.8 & 8.6 \\
\hline
\end{tabular}


high acidogenic potential. This is for instance the case for dried distillers grain with soluble because of the use of sulphuric acid in the production process of bioethanol.

Urea $\mathrm{N}$ excretion by pigs can also be reduced by including fibrous feedstuffs in the diet. With more fermentable non-starch polysaccharides (NSP) in the diet, some of the $\mathrm{N}$ excretion is shifted from urine to bacterial protein in faeces (Canh et al., 1998; Kreuzer et al., 1998; Sørensen and Fernandez, 2003; Jarret et al., 2011, 2012), while total $\mathrm{N}$ excretion is not affected. Moreover, slurry $\mathrm{pH}$ is decreased with the use of fermentable NSP due to volatile fatty acid formation in the hindgut of the pig and in the slurry (Table 15.7). Canh et al. (1998) reported a linear relationship between NSP intake and slurry $\mathrm{pH}$ as well as $\mathrm{NH}_{3}$ volatilisation; for each $100 \mathrm{~g}$ increase in NSP intake, the slurry $\mathrm{pH}$ decreased by 0.12 units and the $\mathrm{NH}_{3}$ emission from slurry decreased by $5.4 \%$. This is consistent with the recent results obtained by Jarret $e t$ al. (2012) who compared two diets differing in their fibre content (Table 15.7).

The utilisation of pig manure $\mathrm{N}$ after field application may also be affected by the level of NSP in the diet, because a greater proportion of $\mathrm{N}$ is excreted in faeces in more complex organic forms. Availability of slurry $\mathrm{N}$ was reduced after the inclusion of dietary fibre with low fermentability (Sørensen and Fernandez, 2003), whereas it was not affected when the dietary content of fermentable structural carbohydrates increased (Gerdemann et al., 2000; Sørensen and Fernandez, 2003), although in all cases the proportion of $\mathrm{N}$ excreted in urine decreased. Combined with the proportion of urinary $\mathrm{N}$, the fibre content of faeces provides a good prediction of the short term availability of slurry N to plants (Sørensen and Fernandez, 2003).

Table 15.7. Effect of fibre content in fattening pigs diet on composition of excreta, nitrogen balance and ammonia emission (Jarret et al., 2012).

\begin{tabular}{llll} 
Item & Control & High-fibre $^{1}$ & \\
\hline Crude fibre, g/kg & 29.4 & 49.0 & \\
Nitrogen balance, g/d & & & \\
$\quad$ Intake & 55.9 & 55.5 & $* * *$ \\
$\quad$ Excretion & 28.7 & 30.3 & $* * *$ \\
$\quad 26.3$ & 40.0 & $* * *$ \\
pH in faeces & 8.28 & 7.15 & $* * *$ \\
pH faeces & 8.39 & 8.11 & $* * *$ \\
VFA ${ }^{2}$ in faeces, mg/l & 62.6 & 260.0 & 12.4 \\
Ammonia emission (\%) & 17.9 & & \\
\hline${ }^{1}$ In the high fibre diet soybean meal was replaced by wheat dried distillers grain with soluble and rapeseed meal. \\
${ }^{2}$ Volatile fatty acids analysed according to Peu et al. (2004).
\end{tabular}


Effects of dietary manipulations on $\mathrm{NH}_{3}$ production from poultry production have been described by Meda et al. (2011). In broilers, Ferguson et al. (1998) measured that litter humidity was reduced by $6 \%, \mathrm{~N}$ excretion by $16.5 \%$ and $\mathrm{NH}_{3}$ volatilisation by $31 \%$, when dietary CP content decreased from 21.5 to $19.6 \%$. It is noticeable that the effect is more marked on $\mathrm{NH}_{3}$ volatilisation than on $\mathrm{N}$ excretion. The effects of dietary sodium $(\mathrm{Na}), \mathrm{K}$ and electrolytic balance on water consumption of broilers and humidity of litter have also been investigated in poultry and indicate that humidity of excreta and litter increase linearly with dietary $\mathrm{Na}$, when fed above the physiological requirements. The recent results of Belloir et al. (2017) confirmed that the reduction of dietary $\mathrm{CP}$ content in finishing broilers decreases $\mathrm{N}$ volatilisation, due to two effects acting in synergy: (1) the direct reduction of $\mathrm{N}$ excretion (Section 15.2.1.); and (2) the lower proportion of excreted $\mathrm{N}$ to be volatilised (minus 4-5 points per $\mathrm{CP}$ point reduction) due to a lower moisture content in the litter.

Feed viscosity appears to be another important criteria affecting water excretion of poultry (Francesch, 2005). In turkey, Carré et al. (1994) showed that water excretion was significantly correlated with feed viscosity, but the best prediction of water excretion was obtained by combining feed viscosity and $\mathrm{K}$ content. This would explain the poor quality of litter when poultry are fed cereals with a high NSP content associated with a high viscosity. In this context, the use of enzymes may contribute to improve litter quality as shown in different studies (Francesch, 2005). The incorporation of some other feed ingredients such as some co-products or leguminous grain may also alter litter quality. The effects of these changes in litter quality on $\mathrm{NH}_{3}$ emission have not been evaluated, but it may be expected that the increased humidity should result in higher emissions.

\subsection{Effect of feed composition on direct emissions of greenhouse gas}

Nutrition may affect both emissions of $\mathrm{N}_{2} \mathrm{O}$ and $\mathrm{CH}_{4}$. According to IPCC (2006), emissions of $\mathrm{N}_{2} \mathrm{O}$ are calculated from $\mathrm{N}$ excretion and specific emission factors that depend on manure management. This means that according to this procedure of calculation, $\mathrm{N}_{2} \mathrm{O}$ emission will be proportional to $\mathrm{N}$ excretion, and all strategies that will reduce $\mathrm{N}$ excretion will also affect direct the calculate $\mathrm{N}_{2} \mathrm{O}$ emissions, in the same proportion, as well in pig and poultry. However, it should be confirmed by experimental results since, to our knowledge, this has not yet been done.

Methane has mainly two origins: enteric fermentations, which are negligible in poultry, and fermentation from collected and stored manure. Enteric fermentations in pigs vary according to age of animals and the amount of digested fibre ingested. The latter is the difference between digested organic matter $(\mathrm{OM})$ and digested protein, 
fat, starch and sugar (Sauvant et al., 2004). The loss of energy as $\mathrm{CH}_{4}\left(\mathrm{E}\left(\mathrm{CH}_{4}\right)\right)$ can be obtained by multiplying digested fibre by 670 or $1,340 \mathrm{~J} / \mathrm{g}$ for growing pigs and sows, respectively (Noblet et al., 2004). Methane production $\left(\mathrm{CH}_{4}\right.$ Enteric, $\left.\mathrm{kg}\right)$ can then be calculated from $\mathrm{E}\left(\mathrm{CH}_{4}\right)$, considering a methane calorific value equal to $56.65 \mathrm{MJ} / \mathrm{kg}$ (IPCC, 2006). This is illustrated in Table 15.7 from the results of Jarret et al. (2012) who compared two diets with different fibre contents in fattening pigs.

According to the IPCC (2006) Tier 2 methodology, $\mathrm{CH}_{4}$ emission from stored manure can be calculated as:

$$
\mathrm{CH}_{4} \text { Manure }(\mathrm{kg})=\mathrm{VS} \times \mathrm{B}_{0} \times \mathrm{FCM}
$$

with VS = volatile solids in excreta, roughly considered as amount of OM excreted $(\mathrm{kg})$, $\mathrm{B}_{0}=$ maximum $\mathrm{CH}_{4}$ producing capacity $\left(\mathrm{m}^{3} / \mathrm{kg} \mathrm{OM}\right)$ and $\mathrm{MCF}=\mathrm{a} \mathrm{CH}_{4}$ conversion factor for the management system considered, expressed as a percentage of maximum potential. Volatile solids excreted depend on the digestibility of feed OM and is mainly affected by dietary fibre content. Volatile solid can be calculated from OM digestibility values in feed tables (Sauvant et al., 2004). This means it is mainly the indigestible $\mathrm{OM}$ content of the diet that will affect $\mathrm{CH}_{4}$ emission from manure. This is illustrated in Table 15.7 from the results obtained in pigs by Jarret et al. (2012) who compared a conventional and a higher fibre diet. Volatile solid excreted per pig per day was significantly increased with the high fibre diet (by 64\%) whereas $\mathrm{B}_{0}$ of excreta did not differ between treatments. This resulted in a $76 \%$ higher $\mathrm{CH}_{4}$ emission per pig during a simulated storage of $100 \mathrm{~d}$, for the high fibre diet. In the same way, when comparing diets with different types of high fibre feed ingredients (rapeseed meal, sugar beet pulp and dried distillers grain with soluble), Jarret et al. (2011) observed only limited differences in $\mathrm{B}_{0}$ values, but a significant increase of excreted VS, resulting in a much higher potential of $\mathrm{CH}_{4}$ emission per pig for the three high fibre diets $(+60 \%)$. When the excreta were fermented in a mesophilic anaerobic digester, the high fibre diet resulted in a $70 \%$ increase in the production of biogas per pig. This indicates that it should be interesting to adapt the composition of the diet according to the chain of waste collection and treatment in order to minimise uncontrolled emissions of $\mathrm{NH}_{3}$ and $\mathrm{CH}_{4}$, and conversely in case of anaerobic digestion to maximise the controlled production of $\mathrm{CH}_{4}$.

Composition of the diet also affects the dynamic of $\mathrm{CH}_{4}$ emission. Although $\mathrm{B}_{0}$ values of excreta from pigs fed a high protein diet $\left(471 \mathrm{l} \mathrm{CH}_{4} / \mathrm{kg} \mathrm{OM}\right)$ tended to be higher than from a low protein diet $\left(449 \mathrm{l} \mathrm{CH}_{4} / \mathrm{kg} \mathrm{OM}\right)$, the emission during storage was accelerated for the low protein diet, in relation with a lower initial $\mathrm{pH}$ and a lower $\mathrm{NH}_{3}$ concentration (Jarret et al., 2011). In the same way, $\mathrm{CH}_{4}$ emission started much faster in effluent from pigs fed a high fibre diet which had also lower $\mathrm{pH}$ and lower $\mathrm{NH}_{3}$ concentration. These results indicate that MCF is affected by duration of storage and depends on the type of diets. For instance in the study of Jarret et al. (2011) for 
the 50 days of storage in mesophilic conditions, MCF varied from $2 \%$ for the high protein diet to $54 \%$ for the high fibre diet (from 18 to $75 \%$ after 100 days of storage), the value for the low protein diet being intermediate.

\subsection{Effect of feed composition on odours}

Odours are mainly associated with volatile compounds that animals excrete, or which are released during manure storage (De Lange et al., 1999). These volatile compounds are generated by the microbial conversion of feed in the large intestine of pigs, in manure pits or in the litter.

Few studies have evaluated the direct effect of diet manipulation on odour production, mainly because it is difficult to assess odours objectively. As mentioned previously, protein nutrition affects $\mathrm{NH}_{3}$ production, but the $\mathrm{NH}_{3}$ production is not well correlated with odour strength (Le, 2006). Using olfactometry, Hayes et al. (2004) showed a significant reduction in both $\mathrm{NH}_{3}$ and odour emissions when CP content was reduced, but this was not observed in all studies. Hobbs et al. (1996) reported that the concentration of nine out of ten odorous compounds in the air was significantly reduced when low CP diets were fed to the pigs. Le (2006) also found a reduction by $80 \%$ in the odour emission, as determined by olfactometry, when dietary $\mathrm{CP}$ was reduced from 18 to $12 \%$. Moreover, the results from the same author suggested an interaction between effects of $\mathrm{CP}$ and fermentable carbohydrates (FC) on odour production suggesting that odour production depends also on the balance between dietary CP and FC. This is in line with the literature review from Le et al. (2005) suggesting that CP and FC would play a major role in the production of odour nuisance from pig production. The manipulation of gut fermentation could also be a way to alter the production of odorous compounds such as skatole (De Lange et al., 1999).

Using a different methodology for assessing 'pleasantness', 'irritation' and 'intensity' scores of odours, Moeser et al. (2003) were able to significantly discriminate between diets differing in composition. The diets that yielded manure with the worst odour were high in sulphur (rich in garlic or feather meal), whereas a purified diet mainly based on starch and casein presented the lowest score (most pleasant). This is in agreement with the $>700 \%$ increase in odour emission measured by Le (2006) with diets supplemented with a sulphur-containing amino acid (methionine) at high levels. 


\subsection{Conclusion}

Improving the efficiency of nutrient utilisation through feeding appears a very efficient way to reduce excretion in slurry and emissions by the animals. In a wholefarm perspective, this is also an efficient way to decrease the import of nutrients, especially N, P and trace elements, from outside the farm, reducing the nutrient load per hectare. Moreover, gaseous emissions from livestock housing and during storage and spreading of manure are also affected whenever animal nutrition is modified, mainly due to changes in chemical composition of the effluents. These changes have significant effects on emissions of greenhouse gas and $\mathrm{N}$ compounds and to some extent on odours. This contributes to lowering the environmental impacts of animal production, and also improving nutrient recycling at whole system level. Modifying diet composition also offers opportunities to increase the potential of energy production from effluents in case of biogas production.

However, in a whole production chain approach, not only the emissions and resource use occurring during the raising of animals should be considered, but also those occurring during the production of the feed ingredients and the use of effluents. This can be achieved using life cycle assessment (Chapter 14, Van Middelaar et al., 2019). With this approach it appears that the step of production of feed ingredients has an important contribution to many of the environmental impacts of pig and poultry production, especially for energy use, emission of greenhouse gas and eutrophication (Basset-Mens and Van der Werf, 2005). This means that diet composition also indirectly affects environment impact of animal production through the choice of feed ingredients. For instance, decreasing dietary $\mathrm{CP}$ content may be an efficient way to reduce $\mathrm{N}$ excretion and consequently $\mathrm{NH}_{3}$ emission, but it may also reduce the emission of greenhouse gas due to the reduced incorporation of soybean meal that may be associated with deforestation (Garcia-Launay et al., 2014). Moreover diet formulation also affects the type of crops to be produced locally or away from the farm with effects on use of land, crop rotation, biodiversity, and capacity of the system to recycle nutrients.

\subsection{Future perspectives}

Intensive research has been conducted in the last three decades with the aim to increase the efficiency of nutrient use in pigs and poultry, and reduce excretion and emissions. The scientific knowledge on nutrient utilisation by animals has been drastically improved, allowing a much more precise evaluation of their requirements. At the same time, new knowledge on nutrient values of feed ingredient and new feed evaluation systems have also been provided. Moreover many innovations in production of diverse enzymes and free amino acids have been developed. This knowledge has been progressively integrated in mathematical models that can be used in practice. 
Although great progress has been achieved in knowledge of pig and poultry nutrition, there is still room for further improvements. This is the case for instance for efficiency of use of amino acids which is still poorly evaluated for most of them. The role of dispensable amino-acid in low protein diets is also not well elucidated, as well as interactions among amino-acids. In the same way, mechanism controlling the digestive and metabolic utilisation of calcium, phosphorus and trace elements are not well understood, neither quantified. Improving this knowledge will allow to improve our prediction models and secure the use of low protein and low mineral diets whilst reducing security margins. Moreover, the recent and drastic progress of knowledge on gut microbiota also offers new opportunities for innovation in the development of enzymes and additives, in order to improve energy and nutrient digestibility.

The drivers for the future of pig and poultry nutrition are also changing with an increased consideration of the societal demand towards production systems with reduced environmental impacts, but also less in competition with human food demand, taking better benefit of by-products and food waste, more local and less dependent on imported feed ingredients, especially of protein sources associated to deforestation, without GMO. This will require new scientific knowledge and the development of innovations for the production of alternative protein sources, such as for example insects of protein extracted from forages. It can also be expected that these changes could result in an increased variability of feed quality over time that will be necessary to manage in practice.

The development of precision feeding is another important aspect to consider for the future of sustainable pig and poultry nutrition. A large diversity of sensors is now available that may give almost real time information on feed composition, housing conditions and animal performance. At the same time feed dispensers allow to control the amount and/or the composition the feed distributed each day to each room/pen/ animal, allowing to better adapt supplies to requirement, which has been shown to be a major diver for reducing excretion. This should also allow to better take account of the expected increase in variability of feed quality over time. This will however require the development of new types of models and decision support systems able to handle and learn from 'big data' and to take decision at real time to control feeding devices.

\section{References}

Aarnink, A.J.A. and Verstegen, M.W.A., 2007. Nutrition, key factor to reduce environmental load from pig production. Livestock Science 109: 194-203.

Adeola, O., 2010. Phosphorus equivalency value of an Escherichia coli phytase in the diets of White Pekin ducks. Poultry Science 89: 1199-1206.

Aftab, U., Ashra, M. and Jiang, Z., 2008. Low protein diets for broilers. World's Poultry Science Journal 62: 688-701. 
Ahmadi, H. and Rodehutscord, M., 2012. A meta-analysis of responses to dietary nonphytate phosphorus and phytase in laying hens. Poultry Science 91: 2072-2078.

Andretta, I., Pomar, C., Rivest, J., Pomar, J., Locatto, P.A. and Radünz Neto, J., 2014. The impact of feeding growing-finishing pigs with daily tailored diets using precision feeding techniques on animal performance, nutrient utilisation, and body and carcass composition. Journal of Animal Science 92: 3925-3936.

Baeza, E., Bernadet, M.-D. and Lessire, M., 2012. Protein requirements for growth, feed efficiency, and meat production in growing mule ducks. Journal of Applied Poultry Research 21: 21-32.

Basset-Mens, C. and Van der Werf, H.M.G., 2005. Scenario-based environmental assessment of farming systems: the case of pig production in France. Agriculture, Ecosystems \& Environment 105: 127-144.

Belloir, P., Méda, B., Lambert, W., Corrent, E., Juin, H., Lessire, M. and Tesseraud, S., 2017. Reducing crude protein content in broiler feeds: impact on animal performance, meat quality and nitrogen balance. Animal 11: 1881-1889.

Bougouin, A., Appuhamy, J.A.D.R.N., Kebreab, E., Dijkstra, J., Kwakkel, R.P. and France, J., 2014. Effects of phytase supplementation on phosphorus retention in broilers and layers: a meta-analysis. Poultry Science 93: 1981-1992.

Bourdon, D., Dourmad, J.Y. and Henry, Y., 1997. Reduction of nitrogen output in growing pigs by multiphase feeding with decreased protein level. $48^{\text {th }}$ Annual Meeting of the E.A.A.P. August 25-28, 1997. Vienna, Austria.

Braude, R., 1980. Twenty five years of widespread use of copper as an additive to diets of growing pigs. In: L'Hermite, P. and Dehandtschutter, J. (eds.) Copper in animal wastes and sewage sludge. Springer, Cham, Switzerland, pp. 3-15.

Canh, T.T., Aarnink, A.J.A., Mroz, Z., Jongbloed, A.W., Schrama, J.W. and Verstegen, M.W.A., 1998. Influence of electrolyte balance and acidifying calcium salts in the diet of growing-finishing pigs on urinary $\mathrm{pH}$, slurry $\mathrm{pH}$ and ammonia volatilisation from slurry. Livestock Production Science 56: 1-13.

Carré, B., Gomez, J., Melcion, J.P. and Giboulot, B., 1994. La viscosité des aliments destinés à l'aviculture. Utilisation pour prédire la consommation et l'excrétion d'eau. INRA Production Animals 7: 369-379.

Centraal Veevoederbureau (CVB), 2000. Veevoedertabel. CVB, Lelystad, the Netherlands.

Corpen, 2003. Estimation des rejets d'azote, phosphore, potassium, calcium, cuivre, zinc des porcs. Influence de la conduite alimentaire et du mode de logement des effluents sur la nature et la gestion des déjections produites. CORPEN ed, Paris, France, $41 \mathrm{pp}$.

De Lange, K., Nyachoti, M. and Birkett, S., 1999. Manipulation of diets to minimize the contribution to environmental pollution. Advances in Pork Production 19: 173-186.

Dourmad, J.Y., Etienne, M., Valancogne, A., Dubois, S., Van Milgen, J. and Noblet, J., 2008. InraPorc: a model and decision support tool for the nutrition of sows. Animal Feed Science and Technology 143: 372-386.

Dourmad, J.Y., Guingand, N., Latimier, P. and Sève, B., 1999a. Nitrogen and phosphorus consumption, utilisation and losses in pig production: France. Livestock Production Science 58: 199-211. 
Dourmad, J.Y., Henry, Y., Bourdon, D., Quiniou, N. and Guillou, D., 1993. Effect of growth potential and dietary protein input on growth performance, carcass characteristics and nitrogen output in growing-finishing pigs. In: Verstegen, M.W.A., Den Hartog, L.A., Van Kempen, G.J.M. and Metz, J.H.M. (eds.) Nitrogen flow in pig production and environmental consequences. EAAP Publication No. 69. Pudoc Scientific Publishers, Wageningen, the Netherlands, pp. 206-211.

Dourmad, J.Y., Sève, B., Latimier, P., Boisen, S., Fernandez, J., Van de Peet-Schwering, C. and Jongbloed, A.W., 1999b. Nitrogen consumption, utilisation and losses in pig production in France, the Netherlands and Denmark. Livestock Production Science 58: 199-211.

Dourmad, J.Y., Van Milgen, J., Valancogne, A., Dubois, J., Brossard, L. and Noblet, J., 2014. Modelling nutrient utilisation in sows: a way towards the optimization of nutritional supplies. In: Sakomura, N.K., Gous, R.M., Kyriazakis, I. and Hauschild, L. (eds.) Nutritional modeling for pigs and poultry. CABI, Wallingford, UK.

European Environment Agency, 2013. EMEP/EEA air pollutant emission inventory guidebook. Available at: http://www.eea.europa.eu/publications/emep-eea-guidebook-2013.

European Food Safety Authority (EFSA) report, 2014. Scientific Opinion on the potential reduction of the currently authorised maximum zinc content in complete feed. EFSA Journal 12: 3668-3745.

Feddes, J.J.R., Ouellette, C.A. and Leonard, J.J., 2000. A system for providing protein for pigs in intermediately sized grower/finisher barns. Canadian Agricultural Engineering 42: 209-213.

Ferguson, N.S., Gates, R.S., Taraba, J.L., Cantor, A.H., Pescatore, A.J., Ford, M.J. and Burnham, D.J., 1998. The effect of dietary crude protein on growth, ammonia concentration, and litter composition in broilers. Poultry Science 77: 1481-1487.

Francesch, M., 2005. Facteurs nutritionnels modifiant l'humidité et la qualité des excreta et de la litière en volailles. Sixièmes Journées de la Recherche Avicole, St Malo, pp. 146-153.

Frapin, D., 1996. Valorisation du phosphore phytyque vegetal chez I'oiseau: intérét et mode d'action des phytases végétales et microbienne. Thesis. Ecole Nationale Supérieure Agronomique de Rennes; SRA, INRA, Centre de Tours, France, 133 pp.

French Agency for Food, Environmental and Occupational Health \& Safety (ANSES), 2013. Opinion of the on the use of zinc oxide in the diet of piglets at weaning to reduce the use of antibiotics. ANSES Opinion. Request No. 2012-SA-0067 Available at: https://tinyurl.com/y66v9kmj

Garcia-Launay, F., Van der Werf, H., Nguyen, T.T.H., Le Tutour, L. and Dourmad, J.Y., 2014. Evaluation of the environmental implications of the incorporation of feed-use amino acids in pig production using Life Cycle Assessment. Livestock Production Science 161: 158-175.

Gerdemann, M.M., Machmüller, A., Frossard, E. and Kreuzer, M., 2000. Effect of different pig feeding strategies on the nitrogen fertilizing value of slurry for Lolium multiflorum. Journal of Plant Nutrition and Soil Science 162: 401-408.

Gesellschaft für Ernährungphysiologie (GfE), 1999. Energie- und Nährstoffbedarf landwirtschaftlicher Nutztiere. 7. Empfehlungen zur Energie- und Nährstoffversorgung der Legehennen und Masthühner (Broiler). DLG-Verlag, Frankfurt a. M., Germany.

Guiziou, F., Dourmad, J.Y., Saint-Cast, P., Picard, S. and Daumer, M.L., 2006. Reducing ammonia volatilisation from pig slurry through the reduction of dietary crude protein and the incorporation on benzoic acid. In: Petersen, S.O. (ed.) $12^{\text {th }}$ Ramiran International Conference. Technology for recycling of manure and organic residues in a whole farm perspective. Vol. I, pp. 71-74. 
Hayes, E.T., Leek, A.B.G., Curran, T.P., Dodd, V.A., Carton, O.T., Beattie, V.E. and O’Doherty, J.V., 2004. The influence of diet crude protein level on odour and ammonia emissions from finishing pig houses. Bioresource Technology 91: 309-315.

Hobbs, P.J., Pain, B.F., Kay, R.M. and Lee, P.A., 1996. Reduction of odorous compounds in fresh pig slurry by dietary control of crude protein. Journal of the Science of Food and Agriculture 71: 508-514.

Igbasan, F.A., Männer, K., Miksch, G., Borriss, R., Farouk, A. and Simon, O., 2000. Comparative studies on the in vitro properties of phytases from various microbial origins. Archives of Animal Nutrition 53: 353-373.

Instytut Fizjologii I Zywienia Zwierzat (IFZZ), 2005. Poultry nutrition standards. Dietary advice and nutritional value of feed S., Rutkowski A. (ed). Wartość pokarmowa pasz. IFŻZ PAN Jabłonna, Omnitech Press, Warszawa, Poland.

INRA-AFZ, 2004. Tables de composition et de valeur nutritive des matières premières destinées aux animaux délevage: porcs, volailles, bovins, ovins, caprins, lapins, chevaux, poissons. D. Sauvant, J.-M. Perez, G. Tran (eds.), $2^{\text {nd }}$ revised edition, INRA, Paris, 301 pp.

International Panel on Climate Change (IPCC), 2006. Guidelines for national greenhouse gas inventories: reference manual. IPCC, Geneva, Switzerland.

Jarret, G., Cerisuelo, A., Peu, P., Martinez, J. and Dourmad, J.Y., 2012. Impact of pig diets with different fibre contents on the composition of excreta and their gaseous emissions and anaerobic digestion. Agriculture Ecosystems and Environment 45: 6204-6209.

Jarret, G., Martinez, J. and Dourmad, J.Y., 2011. Effect of biofuel co-products in pig diets on the excretory patterns of $\mathrm{N}$ and $\mathrm{C}$ and on the subsequent ammonia and methane emissions from pig effluent. Animal 5: 622-631.

Johansen, K. and Poulsen, H.D., 2003. Substitution of inorganic phosphorus in pig diets by microbial phytase supplementation - a review. Pig News and Information 24: 77N-82N.

Jondreville, C. and Dourmad, J.Y., 2005. Le phosphore dans la nutrition des porcs. INRA Productions Animales 18: 183-192.

Jondreville, C., Hayler, R. and Feuerstein, D., 2005. Replacement of zinc sulphate by microbial phytase for piglets fed a maize-soybean meal diet. Animal Science 81: 77-83.

Jondreville, C., Lescoat, P., Magnin, M., Feuerstein, D., Gruenberg, B. and Nys, Y., 2007. Sparing effect of microbial phytase on zinc supplementation in maize-soya-bean meal diets for chickens. Animal 1: 804-811.

Jondreville, C., Revy, P.S. and Dourmad, J.Y., 2003. Dietary means to better control the environmental impact of copper and zinc by pigs from weaning to slaughter. Livestock Production Science 84: 147-156.

Jondreville, C., Revy, P.S., Jaffrezic, A. and Dourmad, J.Y., 2002. Le cuivre dans l'alimentation du porc: oligoélément essential, facteur de croissance et risque potentiel pour l'homme et l'environnement. INRA Productions Animales 15: 247-265.

Jongbloed, A.W. and Lenis, N.P., 1992. Alteration of nutrition as a means to reduce environmental pollution by pigs. Livestock Production Science 31: 75-94.

Jongbloed, A.W., Everts, H., Kemme, P.A. and Mroz, Z., 1999a. Quantification of absorbability and requirements of macroelements. In: Kyriazakis, I. (ed.) Quantitative biology of the pig. CAB International, Wallingford, UK, pp. 275-298. 
Jongbloed, A.W., Mroz, Z. and Kemme, P.A., 1992. The effect of supplementary Aspergillus Niger phytase in diets for pigs on concentration and apparent digestibility of dry matter, total phosphorus, and phytic acid in different sections of the alimentary tract. Journal of Animal Science 70: 1159-1168.

Jongbloed, A.W., Poulsen, H.D., Dourmad, J.Y. and Van der Peet-Schwering, C.M.C., 1999b. Environmental and legislative aspects of pig production in the Netherlands, France and Denmark. Livestock Production Science 58: 243-249.

Juin, H., Nys, Y. and Broz, J., 2001. Comparative evaluation of two phytase preparations in young tukeys fed a wheat-based diet. Archiv fur Geflugelkunde 65: 231-235.

Knowlton, K.F., Radcliffe, J.S., Novak, C.L. and Emmerson, D.A., 2004. Animal management to reduce phosphorus losses to the environment. Journal of Animal Science 82: E173-E195.

Kornegay, E.T., 2001. Digestion of phosphorus and other nutrients: the role of phytases and factors influencing their activity. In: Bedford, M.R. and Partridge, G.G. (ed.) Enzymes in farm animal nutrition. CAB International, Wallingford, UK, pp. 237-271.

Kreuzer, M., Machmüller, A., Gerdemann, M.M., Hanneken, H. and Wittmann, M., 1998. Reduction of gaseous nitrogen loss from pig manure using feeds rich in easily-fermentable non-starch polysaccharides. Animal Feed Science and Technology 73: 1-19.

Latimier, P. and Dourmad, J.Y., 1993. Effect of three protein feeding strategies, for growing-finishing pigs, on growth performance and nitrogen output in the slurry and in the air. Nitrogen flow in pig production and environmental consequences. Pudoc Scientific Publishers, Wageningen, the Netherlands, pp. 242-245.

Latimier, P., Pointillard, A., Corlouër, A. and Lacroix, C., 1994. Influence de l'incorporation de phytase microbienne dans les aliments, sur les performances, la résistance osseuse et les rejets phosphorés chez le porc charcutier. Journées Recherche Porcine France 26: 107-116.

Le, P.H., 2006. Odor from pig production: its relation to the diet. PhD-thesis, Wageningen University, Wageningen, the Netherlands.

Le, P.H., Aarnink, A.J.A., Ogink, N.W.M., Becker, P.M. and Verstegen, M.W.A., 2005. Odor from animal production facilities: its relation to the diet. Nutrition Research Reviews 18: 3-30.

Leclercq, B., 1996. Les rejets azotés issus de l'aviculture: importance et progrès envisageables. INRA Productions Animales 9: 91-10.

Lelis, G.R., Albino, L.F.T., Silva, C.R., Rostagno, H.S., Gomes, P.C. and Borsatto, C.G., 2010. Suplementação dietética de fitase sobre o metabolismo de nutrientes de frangos de corte. Revista Brasileira de Zootecnia 39: 1768-1773.

Létourneau-Montminy, M.P., Narcy, A., Lescoat, P., Bernier, J.F., Magnin, M., Pomar, C., Nys, Y., Sauvant, D. and Jondreville, C., 2010a. Meta-analysis of phosphorus utilisation by broilers receiving cornsoybean meal diets: influence of dietary calcium and microbial phytase. Animal 4: 1844-1853.

Létourneau-Montminy, M.P., Narcy, A., Magnin, M., Sauvant, D., Bernier, J.F., Pomar, C. and Jondreville, C., 2010b. Effect of reduced dietary calcium concentration and phytase supplementation on calcium and phosphorus utilisation in weanling pigs with modified mineral status. Journal of Animal Science 88: 1706-1716.

Maa- ja elintarviketalouden tutkimuskeskus (MTT), 2013. Available at: https://portal.mtt.fi/portal/pa

Mack, S., Bercovici, D., De Groote, G., Leclercq, B., Lippens, M., Pack, M., Schutte, J.B. and Van Cauwenberghe, S., 1999. Ideal amino acid profile and dietary lysine specification for broiler chickens of 20 to 40 days of age. British Poultry Science 40: 257-265. 
Maguire, R.O., Sims, J.T. and Applegate, T.J., 2005. Phytase supplementation and reduced-phosphorus turkey diets reduce phosphorus loss in runoff following litter application. Journal of Environmental Quality 34: 359-369.

Meda, B., Hassouna, M., Aubert, C., Robin, P. and Dourmad, J.Y., 2011. Influence of rearing conditions and manure management practices on ammonia and greenhouse gas emissions from poultry house. World's Poultry Science Journal 67: 441-455.

Moeser, A.J., See, M.T., Van Heugten, E., Morrow, W.E.M. and Van Kempen, T.A.T.G., 2003. Diet and evaluators affect perception of swine waste odour: an educational demonstration. Journal of Animal Science: 3211-3215.

National Research Council (NRC), 1994. Nutrient requirements of poultry, $9^{\text {th }}$ revised edition. National Academy Press, Washington, DC, USA.

National Research Council (NRC), 2012. Nutrient requirements of swine, $11^{\text {th }}$ revised edition. National Academy Press, Washington, DC, USA.

Noblet, J., Sève, B. and Jondreville, C., 2004. Nutritional value for pigs. In: Sauvant, D., Perez, J.M. and Tran, G. (eds.) Tables of composition and nutritional value of feed materials: pigs, poultry, cattle, sheep, goats, rabbits, horses, fish. Wageningen Academic Publishers, Wageningen, the Netherlands and INRA editions, Paris, France, pp. 25-35.

Petersen, S.O., Sommer, S.G., Béline, F., Burton, C., Dach, J., Dourmad, J.Y., Leip, A., Misselbrook, T., Nicholson, F., Poulsen, H.D., Provolo, G., Sorensen, P., Vinnerås, B., Weiske, A., Bernal, M.P., Böhm, R., Juhász, C. and Mihelic, R., 2007. Recycling of livestock manure in a whole-farm perspective. Livestock Science 112: 180-191.

Peu, P., Béline, F. and Martinez, J., 2004. Volatile fatty acids analysis from pig slurry using high-performance liquid chromatography. International Journal of Environmental Analytical Chemistry 84: 1017-1022.

Pfeiffer, A., Henkel, H., Verstegen, M.W.A. and Philipczyk, I., 1995. The influence of protein intake on water balance, flow rate and apparent digestibility of nutrients at the distal ileum in growing pigs. Livestock Production Science 44: 179-187.

Plumstead, P.W., Leytem, A.B., Maguire, R.O., Spears, J.W., Kwanyuen, P. and Brake, J., 2008. Interaction of calcium and phytate in broiler diets. 1. Effects on apparent prececal digestibility and retention of phosphorus. Poultry Science 87: 449-458.

Pomar, C., Pomar, J., Babot, D. and Dubeau, F., 2007. Effet d'une alimentation multiphase quotidienne sur les performances zootechniques, la composition corporelle et les rejets d'azote et de phosphore du porc charcutier. Journées Recherche Porcine France 39: 23-30.

Pomar, C., Pomar, J., Dubeau, F., Joannopoulos, E. and Dussault, J.-P., 2014. The impact of daily multiphase feeding on animal performance, body composition, nitrogen and phosphorus excretions, and feed costs in growing-finishing pigs. Animal 8: 704-713.

Pomar, C., Van Milgen, J. and Remus, A., 2019. Precision livestock feeding, principle and practice. Chapter 18, In: Hendriks, W.H., Verstegen, M.W.A. and Babinszky, L. (eds.) Poultry and pig nutrition - challenges of the $21^{\text {st }}$ century. Wageningen Academic Publishers, Wageningen, the Netherlands, pp. 397-418.

Portejoie, S., Dourmad, J.Y., Martinez, J. and Lebreton, Y., 2004. Effect of lowering crude protein on nitrogen excretion, manure composition and ammonia emission from fattening pigs. Livestock Production Science 91: 45-55.

Poulsen, H.D., 1995. Zinc oxide for weanling piglets. Acta Agriculturae Scandinavica 59: 159-167. 
Poulsen, H.D., 2000. Phosphorus utilisation and excretion in pig production. Journal of Environmental Quality 29: 24-27.

Poulsen, H.D., Jongbloed, A.W., Latimier, P. and Fernandez, J.A., 1999. Phosphorus consumption, utilisation and losses in pig production in France, the Netherlands and Denmark. Livestock Production Science 58: 251-259.

Revy, P.S., Jondreville, C., Dourmad, J.Y. and Nys, Y., 2003. Le zinc dans l’alimentation du porc: oligoélément essentiel et risque potentiel pour l'environnement. INRA Productions Animales 16: 3-18.

Revy, P.S., Jondreville, C., Dourmad, J.Y. and Nys, Y., 2005. Assessment of dietary zinc requirement of weaned piglets fed diets with or without microbial phytase. Journal of Animal Physiology and Animal Nutrition 90: 50-59.

Rousseau, X., Létourneau-Montminy, M., Meme, N., Magnin, M., Nys, Y. and Narcy, A., 2012. Phosphorus utilisation in finishing broiler chickens: effects of dietary calcium and microbial phytase. Poultry Science 91: 2829-2837.

Sales, J., 2013. Effects of pharmacological concentrations of dietary zinc oxide on growth of post-weaning pigs: a meta-analysis. Biological Trace Element Research 152: 343-349.

Sauvant, D., Pérez, J.M. and Tran, G. (eds.), 2004. Tables of composition and nutritional value of feed materials. Institut National de la Recherche Agronomique, Association Française de Zootechnie (INRA-AFZ), Paris, France, 304 pp.

Sauveur, B., 1985, Besoins en minéraux et recommandations d'apport. Revue Alimentation Animale 389: 46-48.

Schlegel, P, Sauvant, D. and Jondreville, C., 2013. Bioavailability of zinc sources and their interaction with phytates in broilers and piglets. Animal 7: 47-59.

Sørensen, P. and Fernandez, J.A., 2003. Dietary effects on the composition of pig slurry and on the plant utilisation of pig slurry nitrogen. Journal of Agricultural Science 140: 343-355.

Travel, A., Bouvarel, I., Aubert, C., Chagneau, A.-M., Hallouis, J.-M., Juin, H., Relandeau, C., Buttin, P., Broz, J. and Lessire, M., 2005. Réduction des rejets en azote et phosphore par voie alimentaire chez le dindon en finition à performances constantes. Sixièmes Journées de la Recherche Avicole: 345-349.

Van Cauwenberghe, S. and Burnham, D., 2001. New developments in amino acid and protein nutrition of poultry as related to optimal performance and reduced nitrogen excretion. $13^{\text {th }}$ European Symposium of Poultry Nutrition. Oct 2001, Blankenberg, Belgium.

Van de Peet-Schwering, C.M.C., Aarnink, A.J.A., Rom, H.B. and Dourmad, J.Y., 1999. Ammonia emissions from pig houses in the Netherlands, Denmark and France. Livestock Production Science 58: 265-269.

Van Kempen, T.A.T.G., 2001. Dietary adipic acid reduces ammonia emission from swine excreta. Journal of Animal Science 79: 2412-2417.

Van Middelaar, C.E., Van Zanten, H.H.E. and De Boer, I.J.M., 2019. Future of animal nutrition: the role of life cycle assessment. Chapter 14, In: Hendriks, W.H., Verstegen, M.W.A. and Babinszky, L. (eds.) Poultry and pig nutrition - challenges of the $21^{\text {st }}$ century. Wageningen Academic Publishers, Wageningen, the Netherlands, pp. 307-314.

Van Milgen, J., Valancogne, A., Dubois, S., Dourmad, J.Y., Sève, B. and Noblet, J., 2008. InraPorc: a model and decision support tool for the nutrition of growing pigs. Animal Feed Science and Technology 143: 387-405. 